\title{
Evaluating Suit Fit using Performance Degradation
}

\author{
Sarah E. Margerum ${ }^{1}$, Matthew Cowley ${ }^{2}$ and Lauren Harvill ${ }^{3}$ \\ Lockheed Martin,Houston, TX, 77058 \\ Elizabeth Benson ${ }^{4}$ \\ MEI Technologies Inc., Houston, TX, 77058 \\ and \\ Sudhakar Rajulu ${ }^{5}$ \\ NASA Johnson Space Center, Houston, TX, 77058
}

The Mark III suit has multiple sizes of suit components (arm, leg, and gloves) as well as sizing inserts to tailor the fit of the suit to an individual. This study sought to determine a way to identify the point an ideal suit fit transforms into a bad fit and how to quantify this breakdown using mobility-based physical performance data. This study examined the changes in human physical performance via degradation of the elbow and wrist range of motion of the planetary suit prototype (Mark III) with respect to changes in sizing and as well as how to apply that knowledge to suit sizing options and improvements in suit fit.

The methods implemented in this study focused on changes in elbow and wrist mobility due to incremental suit sizing modifications. This incremental sizing was within a range that included both optimum and poor fit. Suited range of motion data was collected using a motion analysis system for nine isolated and functional tasks encompassing the elbow and wrist joints. A total of four subjects were tested with motions involving both arms simultaneously as well as the right arm only. The results were then compared across sizing configurations.

The results of this study indicate that range of motion may be used as a viable parameter to quantify at what stage suit sizing causes a detriment in performance; however the human performance decrement appeared to be based on the interaction of multiple joints along a limb, not a single joint angle. The study was able to identify a preliminary method to quantify the impact of size on performance and to develop a means to gauge tolerances around optimal size. More work is needed to improve the assessment of optimal fit and to compensate for multiple joint interactions.

\footnotetext{
${ }^{1}$ Insert Job Title, Department Name, Address/Mail Stop, and AIAA Member Grade for first author.

${ }^{2}$ Insert Job Title, Department Name, Address/Mail Stop, and AIAA Member Grade for second author.

${ }^{3}$ Insert Job Title, Department Name, Address/Mail Stop, and AIAA Member Grade for second author.

${ }^{4}$ Insert Job Title, Department Name, Address/Mail Stop, and AIAA Member Grade for third author.

${ }^{5}$ Insert Job Title, Department Name, Address/Mail Stop, and AIAA Member Grade for fourth author (etc).
} 